\title{
Penerapan CSR “The Green Care School Program” di Pertamina Integrated Terminal Balikpapan
}

\author{
Dwi Wahyu Hidayat \\ Integrated Terminal Manager - Integrated Terminal Balikpapan - \\ dwi.hidayat@pertamina.com \\ Edward Manaor Siahaan \\ Section Head CSR \& SMEPP Region Kalimantan \\ edward.siahaan@pertamina.com \\ Amalia Puspitasari \\ Comdev Officer - Integrated Terminal Balikpapan \\ p.liamalia@gmail.com \\ Susiana \\ Comdev Officer - Integrated Terminal Balikpapan \\ anasusiana.juli19@gmail.com
}

Received: 25 Juni 2020; Revised: 10 Juli 2020; Accepted : 15 Juli 2020; Published : Agustus 2020; Available online : Agustus 2020.

\begin{abstract}
Corporate social responsibility (CSR) is a program where companies integrate social care in their business operations. Pertamina Integrated Terminal Balikpapan as a stateowned company plays an active role through its Corporate Social Responsibility program for the empowerment of communities around the company area. In this regard, this study aims to find out how the implementation of the CSR Program for Green Care School development at SMK N 6 Balikpapan, carried out by Pertamina Integrated Terminal Balikpapan. The results of this study indicate that the implementation of CSR programs implemented by Pertamina Integrated Terminal Balikpapan goes through five phases, namely the identification phase, the phase where social mapping is carried out by Pertamina Integrated Terminal Balikpapan to find out the potential that exists in the community, especially ring one. The preparation and analysis phase, the phase where designing the implementation of CSR systems such as sorting out programs or setting program goals. The approval phase, the phase in which the Pertamina Integrated Terminal Balikpapan presents the results of identification and analysis of social mapping. The implementation phase, the phase where the FGD begins for the selected program, the program is opened and runs with monitoring per activity. Evaluation phase, the final phase to assess the quality of programs that are run regularly. The ultimate goal of this program is to realize the centre of environment school.
\end{abstract}

Keywords: Implementasi CSR, The Green Care School Program, Pertamina Balikpapan 


\section{Pendahuluan}

Indonesia merupakan salah satu negara yang sangat kaya akan sumber daya alamnya, termasuk sumber daya alam yang berdampingan bahkan milik langsung dari masyarakatnya. Banyak perusahaan beroperasi pada lahan yang bersentuhan langsung dengan kehidupan hajat hidup orang banyak. Dalam keadaan seperti ini, perusahaan akan dengan mudah memberikan kemampuan tanggung jawab sosial kepada masyarakat. Tujuan utama dari perusahaan dalam menjalankan kegiatan operasinya adalah untuk memakmurkan pemiliknya dan dianggap sebagai lembaga yang dapat memberikan keuntungan bagi masyarakat, karena dapat membuka kesempatan kerja, menyediakan barang yang dibutuhkan masyarakat untuk dikonsumsi, membayar pajak kepada pemerintah, dan lain-lain, sampai tidak disadari bahwa kegiatan operasi dari perusahaanperusahaan tersebut memiliki berbagai macam kemungkinan dampak yang dapat merugikan.

Kegiatan operasi perusahaan akan berpengaruh pada timbulnya dampak sosial. Dampak tersebut bisa positif maupun negatif. Dampak positif dari operasi sebuah perusahaan merupakan "manfaat sosial" yang diberikan oleh perusahaan kepada lingkunganya, sedangkan dampak negatif merupakan "biaya sosial" yang dikeluarkan perusahaan untuk mengganti kerugian kepada stakeholders akibat kegagalan yang ditimbulkan dari operasi perusahaan. Kelompok stakeholders tersebut mempunyai kepentingan langsung, mereka mempengaruhi atau dipengaruhi dalam pencapaian tujuan (Hunger \& Wheelen, 2003). Perusahaan harus peduli terhadap kondisi-kondisi lingkungan dimana perusahaan, industri, dan pelaku bisnis tersebut mendirikan serta melakukan aktivitas ekonominya. Disamping melakukan aktivitas dalam hal mencari profit yang sebesar-besarnya juga harus memperhatikan lingkungan. Lingkungan yang dimaksud adalah bersifat komprehensif (menyeluruh), baik lingkungan sosial maupun lingkungan alamnya. Lingkungan sosial memperhatikan nilai-nilai kemanusiaan yang erat hubunganya dengan pemenuhan hak-hak atas kesejahteraan dan penghidupan yang layak. Sedangkan perhatian terhadap lingkungan alam sekitar adalah bentuk tanggung jawab dari antisipasi dampak eksploitasi aktivitas industri perusahaan, sehingga diharapkan tidak terjadi kerusakan ekosistem. Menjaga keseimbangan alam adalah hal yang paling penting sehingga 
tidak menimbulkan masalah-masalah baru yang dapat mengganggu aktivitasaktivitas manusia dan alam.

Corporate social responsibility (CSR) adalah sebuah program dimana perusahaan dapat mengintegrasikan kepedulian sosial dalam operasi bisnis mereka. CSR bisa dikatakan sebagai komitmen yang berkesinambungan dari kalangan bisnis, untuk berperilaku secara etis dan memberi kontribusi bagi perkembangan ekonomi seraya meningkatkan kualitas kehidupan dari karyawan dan keluarganya, serta komunitas lokal dan masyarakat luas pada umumnya. CSR yang dimaksudkan dalam hal ini adalah tanggung jawab sosial moral perusahaan terhadap masyarakat. Tanggung jawab moral perusahaan dapat diarahkan kepada banyak hal seperti kepada diri sendiri, kepada karyawan, kepada perusahaan lain, dan seterusnya. Jika kita berbicara tentang tanggung jawab sosial, yang disoroti adalah tanggung jawab moral terhadap masyarakat dimana perusahaan menjalankan kegiatannya, apakah masyarakat dalam arti sempit seperti lingkungan di sekitar sebuah pabrik atau masyarakat luas (Bertens, 2000:292).

Corporate Social Responsibility merupakan suatu elemen penting dalam kerangka keberlanjutan usaha suatu industri yang mencakup aspek ekonomi, lingkungan dan sosial budaya. Definisi secara luas yang di tulis sebuah organiasi dunia World Bisnis Council for Sustainable Development (WBCD) menyatakan bahwa CSR merupakan suatu komitmenberkelanjutan oleh dunia usaha untuk bertindak etis dan memberikan kontribusi kepadapengembangan ekonomi dari komunitas setempat ataupun masyarakat luas, bersamaandengan peningkatan taraf hidup pekerjanya beserta seluruh keluarga (Lee \& Kotler, 2005:3). CSR merupakan salah satu kewajiban yang harus dilaksanakan oleh perusahaan sesuai dengan isi Undang-Undang Republik Indonesia No. 40 Tahun 2007 Tentang Perseroan Terbatas (UUPT) Pasal 74. Dengan adanya undang-undang ini, maka perusahaan/industri atau korporasi-korporasi wajib untuk melaksanakannya atau dengan kata lain sebuah korporasi juga dituntut untuk memperhatikan aspek sosial dan lingkungan selain dari aspek keuangannya.

Pertamina Integrated Terminal Balikpapan berkomitmen untuk menjadi perusahaan bertanggung jawab atas kewajiban sosial dan lingkungan dengan terus menyesuaikan dengan prinsip 
pembangunan berkelanjutan lingkungan. Semua aktivitas Pertamina Integrated Terminal Balikpapan harus dilakukan secara ekonomis, sosial dan lingkungan secara bertanggung jawab. Berangkat dari sebuah tanggung jawab yang sudah dijelaskan di atas, Pertamina Integrated Terminal Balikpapan sebagai bagian dari perusahaan BUMN ikut berperan aktif melalui program Corporate Social Responsibility-nya terhadap pemberdayaan masyarakat yang berada di sekitar kawasan perusahaan. Pertamina memiliki kategori meliputi Pertamina Cerdas, Pertamina Sehat, Pertamina Berdikari dan Pertamina Hijau. Program Green Care school ini termasuk dalam kategori Pertamina Cerdas dan Pertamina Hijau yang dilaksanakan di beberapa sekolah di $\begin{array}{lllll}\text { Balikpapan meliputi: SMK } & \text { N } 6\end{array}$ Balikpapan, SD 03 Patra Darma Balikpapan, MAN 1 Balikpapan dan SDN 03 Balikpapan Utara. Melalui pendekatan lingkungan dan pendidikan, kegiatan ini diharapkan dapat memberdayakan siswa/i untuk meningkatkan generasi inovatif dan sadar akan lingkungan.

Kegiatan yang dilakukan oleh pihak Pertamina Integrated Terminal Balikpapan ini, merupakan sebuah upaya kolektif dari beberapa stakeholders yang ada di masyarakat Kota Balikpapan untuk bersinergi untuk meningkatkan kesadaran siswa dalam upaya pembinaan dan pendidikan siswa di SMK N 6 Balikpapan, SD PD 03 Balikpapan, MAN 1 Balikpapan dan SDN 03 Muara Rapak Balikpapan Utara.

Awalnya sebelum ada bantuan CSR dari Pertamina Integrated Terminal Balikpapan ini, siswa di sekolah Balikpapan belum mengenal konsep green generation. Dalam rangka menyadarkan pentingnya arti menjaga kualitas lingkungan hidup, maka perlu adanya pemahaman pengetahuan lingkungan hidup di lingkungan pendidikan ataupun masyarakat. Oleh karena itu, Pertamina Integrated Terminal Balikpapan melakukan pendampingan dengan Siswa/i green generation di sekolah dampingan dalam Kegiatan Pengelolaan Lingkungan Berbasis Edukasi dan Aksi. Hal itu dilakukan oleh Pertamina untuk memberdayakan siswa/i serta masyarakat setempat menjadi salah satu solusi alternatif dalam menanamkan kepedulian terhadap lingkungan sekolah. Berdasarkan latar belakang masalah maka dirumuskan permasalahan penelitian sebagai berikut: "Bagaimana Implementasi Program Corporate Social Responsibility (CSR) "Green Care School" 
Pertamina Integrated Terminal

Balikpapan di SMK N 6 Balikpapan.

\section{Metode Penelitian}

Metode yang digunakan adalah metode kualitatif dengan pendekatan diskriptif. Lokasi penelitian pada Pertamina Integrated Terminal Balikpapan dan SMK N 6 Balikpapan. Adapun pengambilan informan menggunakan purposive sampling, informan dalam penelitian ini yakni 10 Dinas Lingkungan Hidup, Seksi Kurikulum Dinas Pendidikan Kota Balikpapan, Kepala Sekolah SMK N 6 Balikpapan, siswa anggota Green Generation dan Sahabat Alam (SALAM) Intitut Teknologi Kalimanatan. Teknik pengumpulan data dengan menggunakan observasi, wawancara dan studi pustaka.

\section{Konsep Pemberdayaan Masyarakat}

Secara estimologi pemberdayaan berasal dari kata "berdaya" yang artinya kekuatan kemampuan bertenaga atau mempunyai akal untuk mengatasi sesuatu (KBBI, 2003:241). Dalam bahasa inggris pemberdayaan berasal dari kata "empowerment dan empower" yang artinya pemberdayaan atau memberdayakan. Pemberdayaan berarti usaha memberi daya, kekuatan atau potensi kepada seseorang. Sehingga mereka mempunyai kekuatan atau kemampuan dalam mengatasi segala sesuatu (Suharto, 2009:57). Permendagri RI Nomor 7 Tahun 2007 tentang Kader Pemberdayaan masyarakat dinyatakan bahwa pemberdayaan masyarakat adalah suatu strategi yang digunakan dalam pembangunan masyarakat sebagai upaya untuk mewujdkan kemampuan dan kemandirian dalam kehidupan bermsyarakat, berbangsa dan bernegara. Jadi pemberdayaan masyarakat adalah upaya untuk memberikan perubahan kepada masyarakat dari kemiskinan dan keterbelakangan menjadi masyarakat yang lebih maju dan mandiri melalui peningkatan potensi-potensi yang dimiliki oleh masyarakat itu sendiri.

Konsep pemberdayaan dalam paradigma pembangunan masyarakat pada sebuah komunitas bisa dianggap sebagai konsep yang relatif baik dan membawa manfaat yang lebih besar. Namun dalam implemenatsinya masyarakat tidak akan serta merta ikut dan berpartisipasi penuh dalam program tersebut. Hal tersebut dikarenakan ada beberapa faktor-faktor yang mempengaruhi pemberdayaan masyarakat yang oleh Sumaryadi dijabarkan menjadi 8 faktor yang berpengaruh sebagai berikut:

1. Kesediaan suatu komunitas untuk menerima pemberdayaan 
bergantung pada situasi yang dihadapinya.

2. Pemikiran bahwa pemberdayaan tidak untuk semua orang, dan adanya persepsi dari pemegang kekuasaan dalam komunitas tersebut bahwa pemberdayaan dapat mengorbankan diri mereka sendiri.

3. Ketergantungan adalah budaya, dimana masyarakat sudah terbiasa berada dalam hirarki, birokrasi dan kontrol manajemen yang tegas sehingga membuat mereka terpola dalam berpikir dan berbuat dalam rutinitas.

4. Dorongan dari para pemimpin setiap komunitas untuk tidak mau melepaskan kekuasaannya, karena inti dari pemberdayaan adalah berupa pelepasan sebagian kewenangan untuk diserahkan kepada masyarakat sendiri.

5. Adanya batas pemberdayaan, terutama terkait dengan siklus pemberdayaan yang membutuhkan waktu relatif lama dimana pada sisi yang lain kemampuan dan motivasi setiap orang berbeda-beda.

6. Adanya kepercayaan dari para pemimpin komunitas untuk mengembangkan pemberdayaan dan mengubah persepsi mereka tentang anggota komunitasnya.

7. Pemberdayaan tidak kondusif bagi perubahan yang cepat.

8. Pemberdayaan membutuhkan dukungan sumber daya (resources) yang besar, baik dari segi pembiayaan maupun waktu (Sumaryadi, 2005:156).

Berdasarkan faktor-faktor tersebut diatas, maka hasil dari sebuah upaya pemberdayaan akan sangat tergantung dari masyarakat dan peran serta semua stakeholders yang terlibat dalam program pemberdayaan tersebut.

Dalam pemberdayaan, penguatan kapasitas dan partisipasi masyarakat sangat dibutuhkan untuk memperlancar proses pemberdayaan itu. secara singkat dapat dikatakan bahwa proses pemberdayaan akan berjalan dengan baik apabila adanya penguatan kapasitas dan peningkatan partisipasi masyarakat. Menurut Soetomo pengembangan kapasitas adalah suatu upaya yang berorientasi pada proses bukan hasil (Soetomo, 2011:112). Proses yang dimaksud adalah proses belajar atau lebih tepatnya proses bekerja sambil belajar. Dengan demikian maka dapat kita simpulkan bahwa pengembangan kapasitas mempunyai hubungan dengan pemberdayaan masyarakat. Di dalam 
pemberdayaan, kemampuan sumber daya manusia akan sangat berpengaruh kepada proses pemberdayaan itu sendiri. Selain kepada kapasitas manusianya, kapasitas disini juga mencakup kepada lembaga dan jaringan yang ada di dalam masyarakat. Penguatan kapasitas dilakukan dengan berbagai cara, misalnya, memberikan pelatihanpelatihan. Dengan adanya peningkatan kapasitas pada masyarakat maka diharapkan akan terciptanya masyarakat yang mandiri sesuai dengan tujuan pemberdayaan.

Pemberdayaan masyarakat bertujuan untuk membentuk individu dan masyarakat menjadi mandiri. Kemandirian tersebut meliputi kemandirian berpikir, bertindak, dan mengendalikan apa yang mereka lakukan. Kegiatan pemberdayaan harus dilaksanakan secara menyeluruh mencakup segala aspek kehidupan masyarakat dari dominasi kekuasaan yang meliputi bidang ekonomi, politik, dan sosial budaya. Konsep pemberdayaan dibidang ekonomi adalah usaha menjadikan ekonomi yang kuat, besar, mandiri, dan berdaya saing tinggi dalam mekanisme pasar yang besar dimana terdapat proses penguatan ekonomi lemah.
Keberhasilan dari program pembangunan pada hakekatnya akan ditentukan oleh sejauh mana kebijakan yang diformulasikan tersebut mendapatkan dukungan dari warga masyarkat. Sebagus apapun programprogram dibuat, jika tidak memperhatikan aspirasi masyarakat, pada akhirnya juga akan berakibat kepada kegagalan program tersebut dalam upaya mewujudkan kesejahteraan masyarakat (Suparjan dan Suyatna, 2007:65).

Esensi dari program pemberdayaan masyarakat adalah melibatkan masyarakat dalam pengelolaan dan pemanfaatan sumber daya sosial, lingkungan alam, dan sumber daya manusia dalam kegiatan peningkatan kesejahteraan masyarakat secara ekonomi. Program pemberdayaan masyarakat Desa Margalaksana diwujudkan dalam bentuk partisipasi atau keterlibatan mereka dalam setiap tahap implementasi program mulai tahap perencanaan, pelaksanaan, pemanfaatan hasil usaha sampai dengan monitoring, dan evaluasi. Sutoro mengemukakan bahwa pemberdayaan merupakan proses mengembangkan, memandirikan, menswadayakan, dan memperkuat posisi tawar-menawar masyarakat lapisan bawah terhadap 
kekuatan-kekuatan penekan di segala bidang dan sektor kehidupan.

Indikator keberhasilan yang dipakai untuk mengukur pelaksanaan program pemberdayaan masyarakat adalah bertumpu pada dua aspek yaitu pendidikan dan pemberdayaan lingkungan hidup.

Aspek pendidikan;

a. Terciptanya masyarakat yang memiliki kesadaran, keinginan, dan kemampuan dalam meningkatkan taraf kehidupannya.

b. Kesadaran masyarakat yang mendorong untuk bersikap responsive terhadap suatu peristiwa, baik yang terjadi di dalam maupun di luar masyarakat, baik peristiwa sosial dan budaya maupun gejala alam.

c. Terciptaya keinginan yang kuat dari masyarakat yang merupakan kekuatan motivasional secara intrinsik yang menjadi motor penggerak daya juang masyarakat.

d. Munculnya kemampuan masyarakat yang bersumber dari potensi lingkungan yakni potensi sosial dan budaya serta fisis geografis, yang dapat diberdayakan, sehingga keberdayaan mereka dapat berkelanjutan (Suzanne Kindevatter, 1979:46).
Aspek lingkungan hidup;

a. Terciptanya lingkungan hidup sebagai ruang hidup masyarakat.

b. Terlestarikannya lingkungan hidup jika manusia penghuninya memiliki kepedulian dan rasa tanggung jawab pewarisan kepada generasi beikutnya.

c. Terciptanya pengelolaan lingkungan sebagai usaha secara sadar untuk memelihara memperbaiki mutu lingkungan agar kebutuhan hidup dapat terpenuhi dengan sebaikbaiknya.

d. Terwujudnya masayarakat yang memiliki kearifan, akal budi, dan beretika serta bermoral lingkungan (Sumaatmadja, 1996:35)

\section{Konsep Corporate Social Responsibility}

Definisi dari Corporate Social Responsibility (CSR) telah dikemukakan oleh banyak pakar, diantaranya yang di definisikan oleh Magnan dan Ferrel, yang mendefinisikan CSR sebagai " $A$ business acts in socially responsible mamer whe its decision and account for and balance diverse stakeholder interest" (Susanto, 2007:21). Definisi ini menekankan kepada perlunya memberikan perhatian secara seimbang terhadap kepentingan berbagai stakeholder yang beragam dalam setiap keputusan dan tindakan yang diambil oleh para pelaku bisnis 
melalui perilaku yang secara sosial bertanggung jawab. CSR merupakan suatu pendekatan yang digunakan oleh perusahaan untuk menunjukan tanggung jawab sosialnya terhadap masyarakat sekitar perusahaan sehingga dapat mengembangkan masyarakat. Bentuk tanggung jawab tersebut diselenggarakan dari aspek ekonomi, budaya, sosial, lingkungan hidup sehingga dapat membantu pengembangan generasi selanjutnya, tetapi pengambilan keputusan harus mempertimbangkan setiap stakeholders karena setiap stakeholders memiliki kepentingan masing-masing.

\section{Corporate Social Responsibility} (CSR) merupakan salah satu program yang saat sekarang ini sedang maraknya dicanangkan di setiap perusahaan. Terdapat beberapa nama yang memiliki kemiripan atau bahkan identik dengan CSR antara lainnya Investasi Sosial Perusahaan (Corporate Social Investment/Investing), Pemberian Perusahaan (Corporate Giving), Kedermawanan Perusahaan (Corporate Philantropy), Relasi Kemsyarakatan Perusahaan (Corporate Community Relations), dan Pengembangan Masyarakat (CommunityDevelopmnet) (Suharto, 2007:103). Dalam Peraturan Menteri Negara BUMN nomor PER-
05/MBU/2007 juga membahas mengenai CSR bahkan lebih rinci. Istilah CSR dalam peraturan tersebut dibagi menjadi dua yaitu program kemitraan dan program bina lingkungan. Yang menjadi fokus dalam penelitian ini yaitu program kemitraan. Konsep CSR bidang kemitraan akan dijelaskan melalui beberapa hal yang akan dimulai dari definisi CSR dan kemudian definisi kemitraan. Kemitraan dapat dimaknai sebagai suatu bentuk persekutuan antara dua pihak atau lebih yang membentuk suatu ikatan kerjasama atas dasar kesepakatan dan rasa saling membutuhkan dalam rangka meningkatakan kapasitas dan kapabilitas di suatu bidang usaha tertentu, atau tujuan tertentu, sehingga dapat memperoleh hasil yang lebih baik. Kemitraan dapat dilakukan oleh pihakpihak baik perorangan maupun badan hukum, ataun kelompok-kelompok. Adapun pihak-pihak yang bermitra tersebut dapat memiliki status yang setara atau subordinate, memiliki misi atau misi berbeda tetapi saling mengisi/melengkapi secara fungsional (Sulistiyani, 2006:130).

Produktifitas program CSR mensyaratkan perencanaan, pengembangan, monitoring serta evaluasi program secara sistematik. Tujuan program harus ditetapkan secara 
jelas dan semua persyaratan yang dibutuhkan untuk mencapai tujuan tersebut pun harus diidentifikasi secara cermat. Indikator-indikator pencapaian program pada setiap tahapan perlu ditetapkan secara jelas dan dapat diukur. Ada sangat banyak kegiatan yang dilakukan dan diklaim sebagai program, dan lebih lanjut diklaim sebagai program yang berhasil. Padahal ukuran-ukuran dari keberhasilan program tersebut belum pernah di tetapkan sebelumnya. Ada banyak metode untuk mengukur seberapa signifikan sebuah program yang dirancang untuk perusahaan. Kualitas program dari perusahaan sangat penting untuk perkembangan kelanjutanya kedepan. Akan tetapi metode yang dipilih harus sesuai dengan kebutuhan perusahaan. Salah satunya adalah dari metode pengukuran Logical Framework Analysis (LFA).

Perusahaan juga harus profesional dan kompeten dalam menyusun logika program atau projek. Logical Framework Analysis (LFA) yang menyediakan matriks kerangka logis untuk melihat realisasi programprogram yang telah ditetapkan, memonitor dan mengevaluasi apakah program berjalan sesuai dengan tujuan yang ditetapkan atau tidak. LFA dibuat oleh United States Agency for
International Development (USAID). LFA telah menjadi alat ukur klasik dalam manajemen bantuan CSR (Gasper, 2000:20). LFA memandu perusahaan dalam rancangan, manajemen, dan evaluasi sebuah program. LFA akan mengidentifikasikan suatu hubungan logika antara kumpulan dari cara dan kumpulan dari akhir. Metode tersebut mulai banyak digunakan oleh perusahaan besar sejak tahun 1990-an. Ada beberapa alasan banyak perusahaan besar menggunakan metode LFA, yakni:

1. Untuk membantu proyek menjadi tersusun lebih jelas dan objektif realistik.

2. Untuk mempromosikan pemikiran logika.

3. Untuk memberikan dasar monitoring, evaluasi, dan membuat percancang berifikir dalam istilah evaluasi.

4. Agar lebih fokus

5. Dapat meningkatkan informasi antara pemberi dan penerima (Aune, 2010:688).

LFA diketahui memiliki banyak manfaat. Hal tersebut yang membuat banyak perusahaan menggunkana metode tersebut. LFA akan membantu perusahaan merancang sebuah program menjadi tersusun dengan lebih jelas dan objektif realistik. Menjadi lebih jelas dan 
Jurnal Politik dan Sosial Kemasyarakatan Vol 12 No 2 (2020) : Agustus 2020

objektif realistik karena LFA mencakup analisis rancangan, manajemen, sampai evaluasi. LFA memiliki analisis yang sistematis dan mudah dipahami karena didasarkan pada kerangka logika. Hal tersebut akan membuat analisis CSR lebih fokus kemudian mampu menjembatani komunikasi antara penerima dan pemberi. LFA (Logical Framework Analysis) membantu prosedur analisis melalui fase dari awal pelaksanaan sampai evaluasi. Prosedur analisis dengan LFA didesain secara sistematis dengan memperhatikan Ada banyak metode untuk mengukur seberapa signifikan sebuah program yang dirancang untuk perusahaan. Kualitas program dari perusahaan sangat penting untuk perkembangan kelanjutanya kedepan. Akan tetapi metode yang dipilih harus sesuai dengan kebutuhan perusahaan. Salah satunya adalah dari metode pengukuran Logical Framework Analysis (LFA). Sebagai dampak dari proyek yang dinyatakan dalam tujuan utama, tujuan hasil, output dan input. Fase LFA dapat dilihat melalui Bagan. 1 di bawah ini:

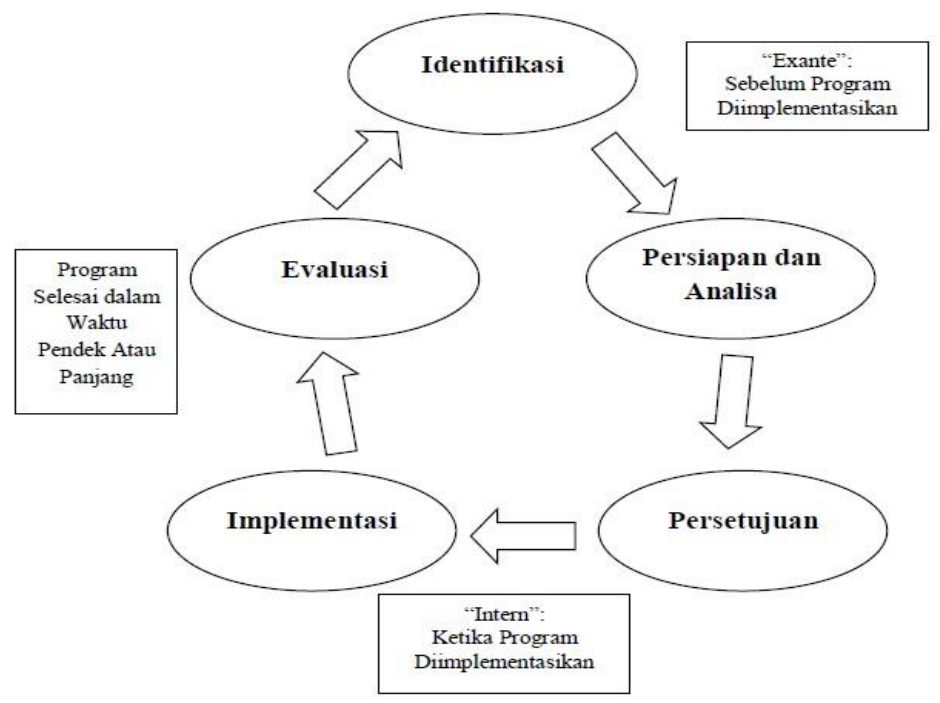

Bagan. I. Fase Siklus Logical Framework Analysis (LFA)

(Barau, 2011:265)

Fase pertama dalam LFA adalah identifikasi yang melibatkan pemangku kepentingan dalam analisis masalah dan desain proyek. Ketika disetujui oleh perusahaan maka tahap selanjutnya adalah fase persiapan dan analisis dimana secara sistematis dan logis menetapkan sistem CSR yang akan dijalankan seperti proyek atau tujuan program. Fase selanjutnya adalah persetujuan dimana proyek CSR boleh dijalankan. Fase keempat adalah implementasi program dimana proyek disetujui dilaksanakan sesuai dengan kesepakatan dalam jangka panjang atau pendek. Fase terakhir yakni evaluasi dimana diadakan pada tempo waktu tertentu yang memutuskan apakah program tersebut dilanjutkan atau tidak. 
Implementasi Program CSR Pertamina Integrated Terminal Balikpapan melalui The Green Care School Program

Sebagai salah satu BUMN terbesar di Indonesia, PT. Pertamina (Persero) memiliki dua tanggung jawab yang besar. Tanggung jawab pertama yaitu meningkatkan profit dalam rangka untuk meningkatkan kesejahteraan negara, sedangkan tanggung jawab yang kedua adalah melaksanakan tanggung jawab sosial dan lingkungan terhadap masyarakat yang khususnya berada di sekitar wilayah operasional perusahaan. Seperti yang diketahui bahwa wilayah operasional Pertamina Integrated Terminal Balikpapan terletak di sekitar kawasan masyarakat. Sehingga secara operasional perusahaan akan berhubungan langsung dengan masyarakat sekitar, misalnya seperti izin, dukungan masyarakat yang akan membuat operasional bisnis dapat berjalan lancar.

Untuk itu, CSR menjadi salah satu jembatan untuk mendapatkan dukungan dari masyarakat. CSR dibuat agar memberikan manfaat sosial, ekonomi dan lingkungan kepada masyarakat terutama di sekitar wilayah operasi perusahaan. Sehingga melalui program Corporate Social Responsibility-nya terhadap pemberdayaan masyarakat yang berada di sekitar kawasan perusahaan, tepatnya di SMK $\mathrm{N} \quad 6$ Balikpapan. Pemberdayaan masyarakat yang dilakukan oleh pihak Pertamina Integrated Terminal Balikpapan ini, merupakan sebuah upaya kolektif dari beberapa stakeholders yang ada di masyarakat Kota Balikpapan untuk bersinergi dalam upaya pembinaan dan pendidikan berwawasan lingkungan di SMK N 6 Balikpapan.

Corporate Social Responsibility (CSR) merupakan tanggung jawab sosial perusahaan. Tanggung jawab sosial perusahaan tersebut adalah berupa tanggung jawab sosial perusahaan kepada para pemangku kepentingan (stakeholders) yang bertujuan untuk meminimalkan dampak negatif dari aktifitas perusahaan dan memaksimalkan dampak positif dari aktifitas perusahaan terhadap sektor ekonomi, sosial dan lingkungan agar mencapai tujuan pembangunan yang berkelanjutan.

Pelaksanaan program Corporate Social Responsibility (CSR) Pertamina Integrated Terminal Balikpapan lebih mengarah pada program Pendidikan dan wawasan lingkungan. Program ini dilakukan dengan mendampingi siswasiswi sekolah melakukan kegiatan 
pelestarian, pemahaman, serta meningkatkan partisipasi warga sekolah dalam bersikap dan peduli pada lingkungan. Pengembangan Program Green Care School yang telah dilaksanakan oleh Pertamina Integrated Terminal Balikpapan di SMK $\quad \mathrm{N} \quad 6$ Balikpapan berfokus pada pelestarian lingkungan dan pemanfaatan energi terbarukan sebagai bentuk upaya mendukung sekolah ADIWIYATA. Program Green Care School merupakan bentuk aksi nyata kesadaran lingkungan untuk peningkatan kualitas Pendidikan serta penunjang edukasi dini kesadaran pengelolaan Lingkungan di lingkup Sekolah, dengan tujuan mewujudkan sekolah binaan menjadi Center of Environment School di Kota Balikpapan.

Output Program Green Care School ini adalah terciptanya sekolah Binaan (SMKN 6 Balikpapan), dengan kurang lebih memiliki 1200 Siswa/i binaan dengan 22 siswa/i sebagai tutor sebaya. Dampak Lingkungan dari program ini adalah; a). 19 Jenis Tanaman Apotek Hidup, b). 15 Jenis Buah, c). 30 Ekor Lele Budidaya, d). 140 Ekor Nila Budidaya, e). 9 Jenis Tanaman Hias.

Program ini juga memberikan beberapa peralatan fasilitas yang berupa; a). 2 Alat Komposting Takakura, b). 1 Mesin Destilasi Plastik, c). 2 Green House
(Kangkung 50 bibit, Sawi 50 bibit, Terong 25 bibit, Strawberry 10 bibit). c). Penanaman tanaman toga (Sirih Hijau 100 bibit, Bawang dayak 400 bibit, Lidah Buaya 100 bibit, Kunyit 400 bibit, Jahe 400 bibit, Kencur 400 bibit, Mint 120 bibit), d). Pemberian unggas peliharaan (Ayam Mutiara 4 ekor, Kalkun 4 ekor, Love Bird 2 ekor, Dara 8 ekor).

Kegiatan program ini juga memunculkan berbagai macam ivovasi baru, diantaranya; 1). Inovasi Paperseed Media tanam, 2). Inovasi Destilasi Plastik, 3). Inovasi Komposting Takakura, 4). Inovasi Marbel Table.

Kegiatan program Green Care School meliputi berbagai rangkaian kegiatan, diantaranya; a). Aquaponic Budidaya Nila, b). Pengembangan seedpaper, c). Pengembangan media tanam hidroponik, d). Kampanye pemakaian tumbler, e). Pengelolaan Green Water, f). Implementasi 3R (Recycle, Reduce, Reuse) ex: kaos bekas menjadi totebag, g). Kampanye lingkungan (Poster Design), h). Coastal Cleaning (Pantai/lingkungan sekolah), i). Destilasi plastik, j). Komposting Takakura.

Selain berbagai kegiatan diatas program Green Care School juga memberikan pemenuhan berbagai fasilitas pendukung, diantaranya; 1). 
Bantuan fasilitas green care school, 2). Bantuan fasilitas green house dan penanaman, 3). Bantuan fasilitas inovasi komposting dan destilasi. 4). Bantuan fasilitas aquaponik dan bibit ikan. Program ini juga melakukan perbaikan dan pengembangan kawasan melalui kegiatan; Penanaman / Zona hijau, Perbaikan tracking dan Pembangunan saung dan dapur resto.

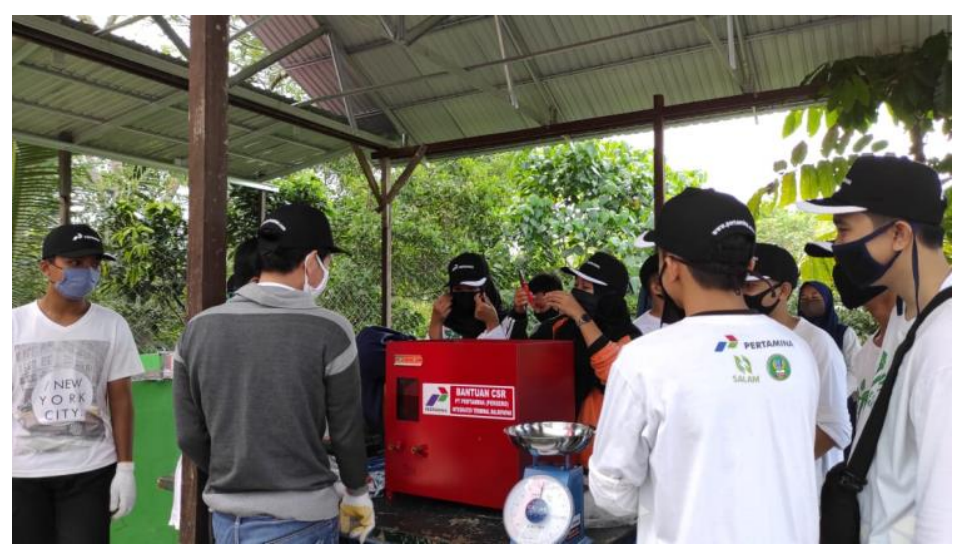

Gambar. 1.

\section{Kegiatan Pemberdayaan Green Care}

\section{School di SMK N 6 Balikpapan.}

Program ini juga menyasar pada peningkatan edukasi bagi seluruh siswa penerima program ini di SMK N 6 Balikpapan. Berupa kegiatan; a). Capacity building siswa/i pengenalan dan pelaksanaan 3R (Recycle, Reduce, Reuse), b). Pelatihan managemen untuk Pendamping Green Generation, c). Pelatihan destilasi plastik dan Komposting, d). Pembiasaan Pilah sampah sejak dini.
Dalam rangka menyadarkan pentingnya arti menjaga kualitas lingkungan hidup, maka perlu adanya pemahaman pengetahuan lingkungan hidup di lingkungan pendidikan ataupun masyarakat. Oleh karena itu, Pertamina Integrated Terminal Balikpapan melakukan pendampingan kepada siswa/i green generation di sekolah dampingan dalam kegiatan pengelolaan lingkungan berbasis edukasi dan aksi. Adapun kegiatan dalam program ini diantaranya yaitu pemberian materi lingkungan hidup melalui metode Tutor Sebaya yang diimplementasikan ke dalam kegiatan pengelolaan sampah berbasis destilasi plastik dan takakura, environment campaign, dan penanaman pohon bersama melalui kerja sama dengan komunitas lingkungan hidup dan komunitas anak muda di Balikpapan sebagai bentuk kegiatan positif dalam membudayakan kebiasaan baik dalam menjaga lingkungan. Sehingga, program ini dapat menjadi salah satu solusi alternatif dalam menanamkan kepedulian terhadap lingkungan sekolah. Implementasi Program CSR Pertamina Integrated Terminal Balikpapan melewati fase dari awal hingga akhir. Penjelasan mengenai fase tersebut dibantu menggunakan alat analisis Logical Framework Analysis (LFA). 
Sebagai pengingat, fase LFA memiliki lima fase, yaitu dari fase identifikasi; fase persiapan dan analisis, fase persetujuan; fase implementasi; fase evaluasi sampai kembali ke fase awal lagi yaitu identifikasi. Fase LFA dipilih karena mampu menjelaskan jalannya proyek secara tersusun lebih jelas.

Fase Logical Framework Analysis CSR Pertamina Integrated Terminal Balikpapan

Melihat implementasi Program CSR yang dilakukan Pertamina Integrated Terminal Balikpapan, maka untuk memulai analisis dilakukan dengan menjawab rumusan masalah dalam penelitian ini yakni bagaimana implementasi Program Green Care School yang telah dilaksanakan oleh Pertamina Integrated Terminal Balikpapan di SMK N 6 Balikpapan. Berdasarkan hasil temuan di lapangan, implementasi program CSR Pertamina Integrated Terminal Balikpapan melewati fase dari awal hingga akhir.

Penjelasan mengenai fase tersebut dibantu menggunakan alat analisis Logical Framework Analysis (LFA). Sebagai pengingat, fase LFA memiliki siklus dari identifikasi; persiapan dan analisis, persetujuan; implementasi; evaluasi sampai kembali ke fase awal lagi. Fase LFA dipilih karena mampu menjelaskan jalannya proyek secara tersusun lebih jelas. Penggunaan LFA sudah dilakukan oleh Pertamina Integrated Terminal Balikpapan sejak awal penerapan CSR sehingga secara konsisten dapat dianalisis dengan baik. hasil analisis didapat berdasarkan wawancara dan observasi dengan staf Pertamina Integrated Terminal Balikpapan.

Fase pertama atau awal dalam pelaksanaan CSR Pertamina Integrated Terminal Balikpapan adalah identifikasi. Identifikasi adalah fase dimana pemetaan sosial dilakukan oleh Pertamina Integrated Terminal Balikpapan. Hal tersebut untuk mengetahui potensipotensi yang ada dilingkungan masyarakat khususnya ring satu. Potensi-potensi yang muncul akan mempermudah mengetahui masalah dan desain proyek selanjutnya. Dalam tahap identifikasi, program Green Care School mulai direncanakan pada tahun 2016. Identifikasi program tersebut melibatkan Dinas Lingkungan Hidup, Seksi Kurikulum Dinas Pendidikan Kota Balikpapan, Kepala Sekolah dan guru SMK N 6 Balikpapan dan Sahabat Alam (SALAM) Institut Teknologi Kalimantan. Selaku pembimbing kegiatan CSR ini. Keterlibatan semua stakeholder ini memunculkan sinergi yang baik dalam 
hal koordinasi teknis pelaksanaan maupun koordinasi mengenai tingkat kebutuhan anggota. Sehingga diharapkan dengan melibatkan anggota penerima manfaat, program Green Care School dapat berkelanjutan karena program tersebut tepat sasaran.

Fase kedua adalah persiapan dan analisis. Dalam fase persiapan dan analisis maka organisasi telah merancang sistem pelaksanaan CSR seperti memilah proyek atau menetapkan tujuan program. Program yang akan dipilih adalah yang memiliki potensi dikembangkan melalui skala prioritas. Skala prioritas bisa berdasarkan kepentingan program dari masyarakat atau skala wilayah. Ide program Green Care School Pertamina Integrated Terminal Balikpapan dilaksanakan bisa berasal dari perusahaan atau inisiatif dari masyarakat. Program Green Care School berawal dari sebuah keresahan generasi muda Balikpapan dalam menyikapi berbagai permasalahan lingkungan hidup, seperti permasalahan sampah yang belum terselesaikan baik di lingkup masyarakat dan lingkup pemerintah, permasalahan kerusakan lahan dan juga belum optimalnya pemanfaatan energi terbarukan. Karena pada saat itu sesuai dengan social mapping, salah satu rekomendasinya adalah program Green Care School. Karena potensi yang ada di Kota Balikpapan adalah tentang kegiatan pengelolaan sampah berbasis destilasi plastik dan takakura, environment campaign, dan penanaman pohon Bersama. Dari permasalahan tersebut terciptalah program Green Generation yang menggandeng berbagai golongan baik instansi pendidikan, pemerintah dan perusahaan. Kegiatan ini dapat terlaksana melalui kerja sama dengan komunitas lingkungan hidup dan komunitas anak muda di Balikpapan sebagai bentuk kegiatan positif dalam membudayakan kebiasaan baik dalam menjaga lingkungan. Potensi ini yang kemudian di analisa oleh Pertamina Integrated Terminal Balikpapan untuk diimplementasikan program CSR-nya.

Fase ketiga adalah fase persetujuan. Dalam fase persetujuan, Pertamina Integrated Terminal Balikpapan memaparkan hasil identifikasi dan analisis data tersebut. Pertamina Integrated Terminal Balikpapan telah menetapkan keputusan mengenai program apa saja yang akan dijalankan. Pengumuman hasil dilakukan oleh Pertamina Integrated Terminal Balikpapan dengan cara melakukan sosialisasi kepada pemangku kepentingan yang dalam hal ini adalah 
instansi pendidikan. Komunikasi pada fase ini perlu dilakukan dengan baik agar program yang telah disetujui dapat berjalan dengan optimal. Setelah Pertamina Integrated Terminal Balikpapan dan pemangku kepentingan setuju mengenai hasil maka segera dilaksanakan pelaksanaan CSR. Setelah fase identifikasi kebutuhan dan di analisa potensi yang ada di SMK N 6 Balikpapan, fase selanjutnya adalah fase persetujuan. Fase ini adalah memaparkan hasil kepada stakehdolers. Pemaparan hasil identifikasi mengenai potensi SMK N 6 Balikpapan disambut antusias oleh Dinas Lingkungan Hidup, Seksi Kurikulum Dinas Pendidikan Kota Balikpapan, Kepala Sekolah SMK N 6 Balikpapan, dan Sahabat Alam (SALAM) Institut Teknologi Kalimantan. Karena selain rekomendasi dari analisis sosial yang dilakukan pada tahap pertama, potensi ini adalah usulan dari para Kepala Sekolah tersebut. Sehingga program Green Care School berawal dari bottom up, diharapkan hasilnya adalah maksimal dan tepat sasaran.

Fase keempat adalah pelaksanaan atau implementasi diisi dengan FGD (Forum Group Discussion) bagi program yang terpilih. Dalam FGD akan didiskusikan mengenai mekanisme program yang akan dijalankan.
Kesepakatan dari pihak Pertamina Integrated Terminal Balikpapan dan seluruh sekolah penerima program harus sejalan. Termasuk juga kesepakatan akan dilakukan monitoring berkala per kegiatan. Setelah sepakat maka program dibuka dan berjalan. Program berjalan selama 6 (enam) bulan maka akan dievaluasi oleh Pertamina. Implementasi program Green Care School secara teknis pelaksanaanya dirancang dan di diskusikan dengan Kepala Sekolah SMK N 6 Balikpapan dan Sahabat Alam (SALAM) Institut Teknologi Kalimantan. Implementasi program CSR Pertamina Integrated Terminal Balikpapan meliputi pendampingan dalam kegiatan pengelolaan lingkungan berbasis edukasi dan aksi. Adapun kegiatan dalam program ini diantaranya yaitu pemberian materi lingkungan hidup melalui metode edukasi dan aksi oleh Tutor sebaya yang diimplementasikan ke dalam kegiatan pengelolaan sampah berbasis destilasi plastik dan takakura, environment campaign, dan Green House. Kegiatan tersebut merupakan kegiatan yang saling terintegrasi sesuai dengan skema inovasi yang dikembangkan pada program Green Care School SMK N 6 Balikpapan.

Fase kelima atau evaluasi. Evaluasi perlu dilaksanakan secara berkala untuk menjaga kualitas program 
yang dijalankan. Evaluasi dilakukan melalui survei IKM (Indeks Kepuasan Mayarakat). Hasilnya juga tertulis dalam laporan resmi Pertamina Integrated Terminal Balikpapan. Ada dua syarat program dapat dilanjutkan yakni program dapat dikembangkan dan penerima program antusias. Jika kedua syarat tersebut terpenuhi maka program dapat dilanjutkan kembali selama 6 (enam) bulan. Sedangkan jika tidak maka program tidak dilanjutkan sesuai dengan kesepakatan awal. Evaluasi dilakukan oleh internal perusahaan Pertamina Integrated Terminal Balikpapan. Indeks Kepuasan Masyakarat ini bertujuan untuk mengukur sejauhmana tingkat keberhasilan program dari perspektif sasaran penerima program (benefeciaries). Dimensi aspek yang diukur adalah perfoma program yang meliputi kapasitas pendamping, keterlibatan peserta, sistem dan komitmen perusahaan dalam rangka pengembangan masyarakat khususnya program Green Care School di SMK N 6 Balikpapan. Hasil dari indeks kepuasan masyarakat ini sangat bermanfaat untuk perbaikan dan kesempurnaan program agar kedepannya lebih baik lagi. Laporan IKM Tahun 2018 menunjukkan hasil yang positif, yaitu hasil IKM dari program Pembinaan Green Care School ini termasuk kategori sangat baik dengan nilai konversi 83,19\%. Pada tahun 2019 dilakukan lagi survei IKM dan menunjukan kategori sangat baik dengan nilai konversi 76,16\%. Sehingga Program ini layak untuk dilanjutkan karena adanya respon masyarakat yang positif dan berantusias tinggi dan mau berusaha mengembangkan program CSR Pembinaan Green Care School di SMK N 6 Balikpapan.

\section{Kesimpulan}

Implementasi Program CSR Pembinaan Green Care School di SMK N 6 Balikpapan oleh Pertamina Integrated Terminal Balikpapan dapat diambil beberapa kesimpulan. Kesimpulan tersebut dipaparkan sebagi berikut :

1. Implementasi Program CSR Pembinaan Green Care School di SMK N 6 Balikpapan, telah melewati beberapa fase. Fase tersebut antara lain adalah fase identifikasi, fase persiapan dan analisis, fase persetujuan, fase pelaksanaan dan fase evaluasi. Program CSR Pembinaan Green Care School berawal dari inisiatif Kepala Sekolah, guru dan siswa SMK N 6 Balikpapan, sehingga program ini merupakan usulan dari bawah (Bottom up). Program CSR Pembinaan Green Care School tersebut termasuk dalam 
kluster pendidikan dan lingkungan. Program menyentuh simpul-simpul pendidikan lingkungan bagi seluruh siswa di sekolah sasaran program. Implementasi program diantaranya dalam bentuk pendampingan dalam kegiatan pengelolaan lingkungan berbasis edukasi dan aksi tutor sebaya. Adapun kegiatan dalam program ini diantaranya yaitu pemberian materi lingkungan hidup melalui metode edukasi dan aksi yang diimplementasikan ke dalam kegiatan pengelolaan sampah berbasis destilasi plastik dan takakura, environment campaign, dan penanaman pohon Bersama di green house.

2. Pada setiap fase Program CSR Pembinaan Green Care School, penerima manfaat dilibatkan secara partisipasi, sehingga penerima manfaat dijadikan sebagai obyek sekaligus sebagai subyek dalam penyusunan strategi pelaksanaan program-program CSR Pembinaan Green Care School. Sehingga kendala dan permasalahan yang terjadi pada saat pelaksanaan program CSR selama ini dapat diketahui secara langsung dengan yang berkaitan. Sehingga pelaksanaan program cenderung berjalan lancar dan tanpa kendala berarti. Tujuan akhir dari program ini adalah terciptanya "The Centre of Environment School" di Balikpapan melalui SMK $\quad \mathrm{N} \quad 6$ Balikpapan.

\section{Daftar Pustaka}

Aune, Jens B. (2010). "Logical Framework Approach and PRA Mutually Exclusive or Complementary Tools for Project Planning?" Development in Practice. Vol. 5, pp. 687-690. London : Routledge.

Barau, D.A. and Olukosi, J.O. (2011). "LFA : An Essential Tool for Designing Agricultural Project Evaluation." Nigerian Journal of Basic and Applied Sciene. Vol.19. No.2, pp 260-268. Grahamstown : AJOL.

Bertens, K. 2000. Pengantar Etika Bisnis. Yogyakarta : Kanisius.

Gasper, Des. (2000). "Evaluating The Logical Framework Analysis Approach Towards Learning Oriented Development Evaluation." Public Administration and Development. Vol. 20, pp. 17-28. Hoboken : John Wiley \& Sons.

Hunger, J. David and Thomas L Wheelen. (2003). Essential of Strategic 
Management. New Jersey : Prentice Hall.

Kamus Besar Bahasa Indonesia (KBBI). 2003.

Kindevater, Suzanne. 1977. Non Formal

Education As An Empowering Process. Amhers: Center For International Education.

Lee, Nancy dan Kotler, Philip. 2005. Corporate Social Responsibility : Doing the Most Good for Your Company and Your Cause. New Jersey : John Wiley and Sons.

Soetomo. 2011. Pemberdayaan Masyarakat, Mungkinkah Muncul Antitesisnya ?. Yogyakarta : Pustaka Pelajar.

Suharto, Edi. 2007. Pekerjaan Sosial di Dunia Industri. Bandung : Refika Aditama.

Suharto, Edi. 2009. Membangun Masyarakat Memberdayakan Rakyat. Bandung: PT Refika Aditama.

Sulistiyani, A, T. 2006. Kemitraan dan Model-model Pemberdayaan. Yogyakarta : Gava Media.

Sumaatmadja, Nursid. 1996. Manusia dalam Konteks Sosial, Budaya dan Lingkungan Hidup. Bandung: Alfabeta.
Sumaryadi, I Nyoman. 2005. Efektivitas Implementasi Kebijakan Otonomi Daerah. Jakarta : Citra Utama.

Suparjan dan Hempri Suyatna. 2007. Pengembangan Masyarakat dari Pembangunan sampai Pemberdayaan. Yogyakarta : Aditya Media.

Susanto. 2007. A Strategic Management Approach, Corporate Social Responsibility. Jakarta : Jakarta Consulting Group. 